\title{
Simulation of Parameters of Coaxial Solar Cells Based on Si and InP Nanowires
}

\author{
I.P. Buryk ${ }^{1}$, L.V. Odnodvorets ${ }^{2, *}$, Ya.V. Khyzhnya ${ }^{2}$ \\ ${ }^{1}$ Konotop Institute of Sumy State University, 24, Myru Ave., 41615 Konotop, Ukraine \\ 2 Sumy State University, 2, Rymsky-Korsakov St., 40007 Sumy, Ukraine
}

(Received 05 January 2021; revised manuscript received 20 February 2021; published online 25 February 2021)

\begin{abstract}
The use of photovoltaic solar energy converters with nanowire solar cells is a promising direction for further development of photovoltaics. Along with this, significant interest in the properties of $\mathrm{Si}$, InP, GaAs, InGaN nanowires as elements of high-efficiency photoconverters has formed a new direction of nanowire photovoltaics. The most relevant is the study of structural, optical, electrical, temperature and other characteristics of semiconductor nanowires. The paper presents the results of numerical simulation of coaxial $p-i-n$ structures of solar cells based on $\mathrm{Si}$ and InP nanowires. The geometry of the 3D structures, light and dark current-voltage characteristics are designed using Silvaco TCAD tools. Within the framework of the drift-diffusion transport model with Fermi-Dirac statistics, the admissible values of the electrical parameters such as the open-circuit voltage $U_{O C}$, short-circuit current density $J_{S C}$, maximum power $P_{m}$, fill-factor FF, photovoltaic efficiency $\eta$ and others are obtained. The temperature dependence of the current-voltage characteristics and electrical parameters is investigated. The temperature coefficients of the open-circuit voltage, short-circuit current density, fill-factor and efficiency for coaxial nanowire solar cells based on $\mathrm{Si}$ and $\mathrm{InP}$ are determined in the temperature range from 300 to $400 \mathrm{~K}$. It is concluded that the thermal stability of the electrical parameters for InP-based photovoltaic converter is high, which is characteristic of direct band gap semiconductors. The obtained results of numerical simulation are in good agreement with the experimental data and can be used to predict the properties of nanowire solar cells.
\end{abstract}

Keywords: Nanowire solar cell, Simulation, Temperature effects of electrical parameters.

\section{INTRODUCTION}

The ability to integrate high-quality low-cost materials with excellent optoelectronic properties and better electrical parameters is the advantage of nanowire photovoltaic converters compared to other photovoltaic structures of equivalent volume (thin-film, planar, bulk materials). A wide range of materials based on metals and semiconductors such as multilayer, multicomponent and heterogeneous films of micron and nanoscale thickness [1-3], including high-entropy film alloys [4] etc., are used in modern opto- and nanoelectronics. Photovoltaic converters as portable energy sources have found wide application in sensor electronics, power engineering, medical equipment [5-9].

It should be noted that currently nanowire solar cells have achieved high efficiency: $10.2 \%$ for horizontal structures and $40.0 \%$ for vertical ones [10], which contributes to the development of new high-efficiency and low-cost nanowire photovoltaic converters [10-12], in particular, tandem or axially tandem, branched, inorganic/organic hybrid, on flexible substrates and substrates of glass, amorphous silicon, graphene, carbon nanotubes, etc.

The constant search for improving solar energy collection methods using photovoltaic converters causes considerable interest in coaxial $p-i-n$ structures based on nanowires and in the study of their properties and characteristics [10-12]. Nanowire arrays have optimal capture of a wide part of the solar spectrum, which provides efficient collection of solar energy and the minimum diffusion path length of charges, etc. Si, InP, GaAs, AlAs-GaAs and others are most widely used for the fabrication of nanowire solar cells.
Along with this, similar data for photovoltaic converters, for example, based on Si and GaAs, can be verified or simulated using Silvaco TCAD [13] and Comsol Multiphysics [14] software simulators for better understanding the physical processes in such materials.

Let us consider the elements of theoretical physics as a basis for numerical simulation in the Atlas system (Silvaco TCAD simulator) [15].

The electrostatic potential is related to the space charge density by the Poisson equation [15]:

$$
\operatorname{div}(\varepsilon \nabla \psi)=-\rho
$$

where $\psi$ is the electrostatic potential, $\varepsilon$ is the local permittivity, and $\rho$ is the local space charge density.

The following equation establishes the relationship between the electric field strength and the electric potential (vector quantities are marked in bold):

$$
\mathbf{E}=-\nabla \psi
$$

The continuity equations determine the rates of change of carrier concentrations:

$$
\begin{aligned}
& \frac{\partial n}{\partial t}=\frac{1}{q} \operatorname{div} \mathbf{J}_{n}+G_{n}-R_{n}, \\
& \frac{\partial p}{\partial t}=\frac{1}{q} \operatorname{div} \mathbf{J}_{p}+G_{p}-R_{p},
\end{aligned}
$$

where $\mathbf{J}_{n}$ and $\mathbf{J}_{p}$ are the electron and hole current densities, $G_{n}$ and $G_{p}$ are the generation rates for electrons and holes, $R_{n}$ and $R_{p}$ are the recombination rates for electrons and holes, and $q$ is the elementary charge.

\footnotetext{
*larysa.odnodvorets@gmail.com
} 
Equations for determining the values of $\mathbf{J}_{n}, \mathbf{J}_{p}, G_{n}$, $G_{p}, R_{n}$ and $R_{p}$ are different depending on the transport model used. The basic drift-diffusion transport model is the simplest model in Atlas. The disadvantage of using it is less accuracy for small objects. Equations of the basic drift-diffusion transport model are written as:

$$
\begin{aligned}
& \mathbf{J}_{\boldsymbol{n}}=q n \mu_{n} \mathbf{E}_{\boldsymbol{n}}+q D_{n} \nabla n, \\
& \mathbf{J}_{\boldsymbol{p}}=q n \mu_{p} \mathbf{E}_{\boldsymbol{p}}-q D_{p} \nabla p,
\end{aligned}
$$

where $\mu_{n}$ and $\mu_{p}$ are the carrier mobilities for electrons and holes, $D_{n}$ and $D_{p}$ are the diffusion coefficients for electrons and holes.

The further solution of the problem is associated with the determination of the diffusion coefficients. For this purpose, the well-known Boltzmann and FermiDirac statistics are used. It should be noted that the latter is more suitable when modeling high-doping regions and small-size objects.

Einstein's equation for the diffusion coefficients in the framework of Boltzmann statistics is as follows:

$$
D=\frac{k T_{L}}{q} \mu
$$

where $k$ is the Boltzmann constant and $T_{L}$ is the lattice temperature.

Equations for the diffusion coefficients within the framework of Fermi-Dirac statistics for electrons (the similar expressions are also used for holes) are:

$$
\begin{gathered}
D=\frac{\left(\frac{k T_{L}}{q} \mu_{n}\right) F_{1 / 2}\left\{\frac{1}{k T_{L}}\left[\varepsilon_{F_{n}}-\varepsilon_{c}\right]\right\}}{F_{-1 / 2}\left\{\frac{1}{k T_{L}}\left[\varepsilon_{F_{n}}-\varepsilon_{c}\right]\right\}}, \\
\varepsilon_{F_{n}}=-q \phi_{n}=\psi-\frac{k T_{L}}{q} \ln \left(\frac{n}{n_{i e}}\right),
\end{gathered}
$$

where $F_{\alpha}$ is the Fermi-Dirac integral of the order of $\alpha$, $\varepsilon_{c}$ is the conduction band energy, $\varepsilon_{F_{n}}$ is the given quasiFermi level, $\phi_{n}$ is the quasi-Fermi potential, and $n_{i e}$ is the effective intrinsic carrier concentration.

The disadvantage of using the basic drift-diffusion model is that it does not take into consideration quantum effects, such as the wave nature of charge carriers. In a nanowire solar cell, the movement of charge carriers is limited in one direction. This affects the radial density of charges and states. Quantum effects can be simulated in the Self-Consistent Coupled SchrödingerPoisson Model, but it cannot independently take into account the transport properties of materials. Therefore, this model is used in combination with the DriftDiffusion Mode-Space Method or the Mode Space NonEquilibrium Green's Function Approach. Note that for the simulation of nanowire devices in Atlas, the Schrödinger equation in cylindrical coordinates is solved, whose form for electrons and holes can be found in [15].

Along with this, a promising direction of research is the study of temperature dependences of the parameters of solar cells [16-18]. Thus, in [15], the physics of the processes that determine the temperature sensitiv- ity of photovoltaic converters is discussed and the method of determining the temperature coefficients of the electrical parameters of nanowire solar cells (the open-circuit voltage $U_{O C}$, short-circuit current density $J_{S C}$, fill-factor FF, efficiency $\eta$ ) is presented.

The effect of temperature on the values of $U_{O C}, J_{S C}$, FF and $\eta$ for Si-based nanowire solar cells is investigated by the authors of [18]. The typical character of the temperature dependences is obtained, but a decrease in the value of $J_{S C}$ with increasing temperature is observed, which may be associated with an increase in the effect of surface recombination of charge carriers.

These processing conditions formed the aim of this work, namely, the numerical simulation using Silvaco TCAD tools of the operating parameters of nanowire solar cells as a function of materials $(\mathrm{Si}, \mathrm{InP})$ and the exploitation temperature.

\section{NUMERICAL SIMULATION PROCEDURE}

Coaxial $p-i-n$ structures of nanowire solar cells were designed and examined using Silvaco TCAD tools. As a feature of the program code, it should be noted that in the Atlas simulator, a general cylindrical structure was created by means of the mesh cylindrical three.d operator, where the parameter cylindrical allowed to set the radius, angle and $Z$-coordinates. The parameter three.d informed the simulator about the formation of a $3 \mathrm{D}$ mesh. During the execution of the program code, the simulator prepared a report in the form of numerical data on the electrical parameters of the designed structures, displayed dark and light (AM1.5G illumination, 1 sun) current-voltage characteristics and 3D geometry.

Taking into account the dimensionality of the studied structures, concentration distributions of impurities and the temperature dependence, the physical features of charge transport were taken into account using the models fermi ni.fermi cvt srh temperature operator. The parameter fermi made it possible to specify the drift-diffusion transport of charges within the framework of Fermi-Dirac statistics. The parameter srh allows to take into consideration many physical processes, including Shockley-Read-Hall recombination mechanisms, which are dominant in such structures and must be taken into account when simulating their electrical parameters.

\section{DEVICE STRUCTURE}

This part of the work presents the results of numerical simulation of coaxial $p-i-n$ structures of nanowire solar cells based on Si and InP. The photovoltaic element located between the electrodes (see Fig. 1a) has a total length of $3110 \mathrm{~nm}$ and a diameter of $380 \mathrm{~nm}$. It consists of a $p$-type central layer, a neutrally charged $i$-type inner layer and a negatively charged $n$-type outer layer. When a photon hits the nanowire, it generates an electron-hole pair in its $i$-region. The electrons move radially from the center to the diffusion-depleted contact layer of the outer $n$-shell, while the holes move inward toward the diffusion-depleted layer of the $p$-region. The advantage of a circular cross-section is that electrons and holes must move a much shorter distance than in a flat cell in order to reach the contacts that collect them. 


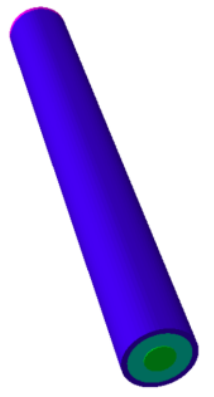

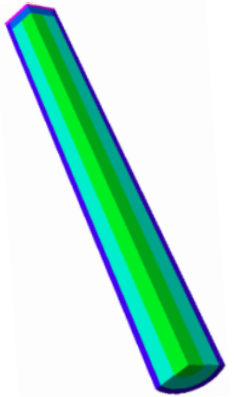

$\mathrm{b}$
Fig. 1 - 3D geometry of a coaxial $p-i-n$ structure of a nanowire solar cell (a) and the corresponding slice with displaying the individual regions (b)

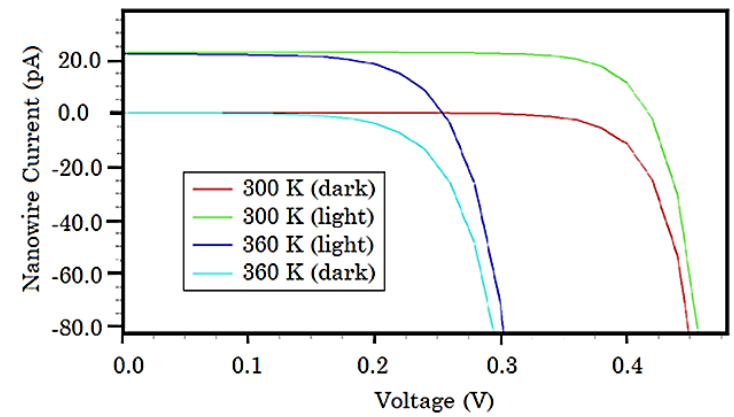

Fig. 2 - Dark and light current-voltage characteristics of the Si-based nanowire solar cell for temperatures of 300 and $360 \mathrm{~K}$

To calculate the electrical characteristics of coaxial photovoltaic elements based on $\mathrm{Si}$ and $\mathrm{InP}$ nanowires, the same geometric structures were chosen (Fig. 1b) with the following parameters: for the $p$-region, the length is $3000 \mathrm{~nm}$ and the diameter is $160 \mathrm{~nm}$; for the $i$-layer, the length is $2995 \mathrm{~nm}$ and the thickness is $80 \mathrm{~nm}$; for the $n$-layer, the length is $3075 \mathrm{~nm}$ and the thickness is $30 \mathrm{~nm}$. The air gap, which served as an insulator for the $i$ - $n$ regions relative to the anode, had a thickness of $5 \mathrm{~nm}$. The near-contact layer of the cathode was $30 \mathrm{~nm}$ thick and doped with a donor impurity with a concentration of $5 \times 10^{17} \mathrm{~cm}^{-3}$. The material of the electrodes was determined by default by Atlas and their thickness was chosen to be minimal. Between the near-contact layer of the cathode and the $i$-region there was a separation region of a thickness of $80 \mathrm{~nm}$ with a donor impurity concentration of $1 \times 10^{14} \mathrm{~cm}^{-3}$. When designing the structures, the following configuration of the doping profiles of the base layers was used: the concentration of the acceptor impurity in the volume of the nucleus was $4 \times 10^{16} \mathrm{~cm}^{-3}$; the intermediate region was doped with a donor impurity with a concentration of $1 \times 10^{14} \mathrm{~cm}^{-3}$; the outer layer had a higher concentration of donor impurity equal to $5 \times 10^{17} \mathrm{~cm}^{-3}$.

As an example, Fig. 2 shows typical simulated dark and light current-voltage characteristics for coaxial $p-i-n$ structures of Si-based nanowire solar cells at different temperatures.

It should be noted that the value of the short-circuit current density $J_{S C}$ was defined as the ratio of the current in the nanowire (Fig. 2) to its cross-sectional area. When displaying the current at the cathode, the designation $1 \mathrm{pA}=1 \times 10^{-12} \mathrm{~A}$ is used. Such a dimension of this quantity is typical for nanowire solar cells and is consistent with the data of [1-7]. Analysis of the electrical parameters for the designed coaxial $p-i-n$ structures obtained on the basis of current-voltage characteristics at different temperatures is given in the next section.

\section{SIMULATION AND RESULTS}

The typical light current-voltage characteristics for coaxial $p-i-n$ structures of Si-based nanowire solar cells at temperatures of $280,300,340,360,380$ and $400 \mathrm{~K}$ are shown in Fig. 3. Based on these data and using the Atlas simulator, the main electrical parameters of photovoltaic converters are determined: open-circuit voltages $U_{O C}$, short-circuit current densities $J_{S C}$, maximum cathode current $I_{m}$, maximum anode voltage $U_{m}$, maximum power $P_{m}$, fill-factors $\mathrm{FF}$, and photovoltaic efficiency $\eta$ (Table 1), which are in good agreement with the experimental results of other authors [1-7].

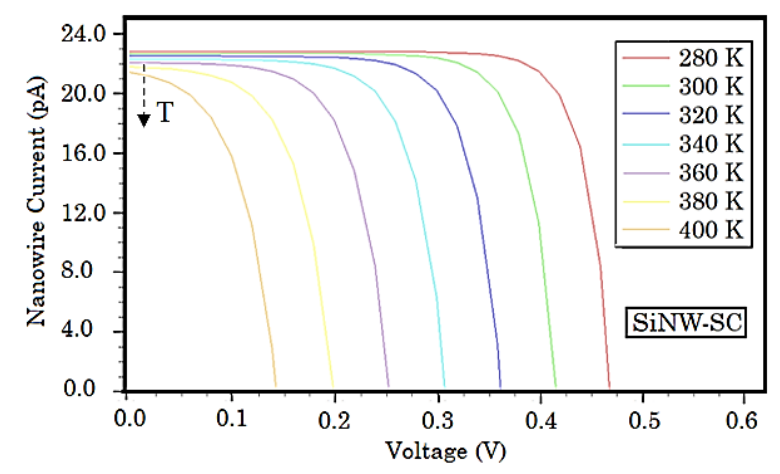

Fig. 3 - Light current-voltage characteristics of the Si-based nanowire solar cell as a function of temperature variations. The arrow direction indicates an increase in temperature

Table 1 - The parameters values used for the Si-based nanowire solar cell as a function of temperature variations

\begin{tabular}{|c|c|c|c|c|c|c|c|}
\hline $\begin{array}{c}\text { Para- } \\
\text { meters }\end{array}$ & $\mathbf{2 8 0} \mathbf{K}$ & $\mathbf{3 0 0} \mathbf{K}$ & $\mathbf{3 2 0} \mathbf{K}$ & $\mathbf{3 4 0} \mathbf{K}$ & $\mathbf{3 6 0} \mathbf{~ K}$ & $\mathbf{3 8 0} \mathbf{~ K}$ & $\mathbf{4 0 0} \mathbf{~ K}$ \\
\hline$U_{O C}, \mathrm{~V}$ & 0.47 & 0.42 & 0.36 & 0.31 & 0.25 & 0.20 & 0.14 \\
\hline $\begin{array}{c}J_{S C} \\
\mathrm{~mA} / \mathrm{cm}^{2}\end{array}$ & 20.11 & 20.02 & 19.93 & 19.67 & 19.49 & 19.23 & 18.96 \\
\hline$U_{m}, \mathrm{~V}$ & 0.40 & 0.34 & 0.30 & 0.24 & 0.20 & 0.14 & 0.08 \\
\hline$I_{m}, \mathrm{pA}$ & 21.50 & 21.40 & 20.20 & 20.00 & 18.25 & 18.27 & 15.80 \\
\hline$P_{m}, \mathrm{pW}$ & 8.60 & 7.30 & 6.10 & 4.80 & 3.60 & 2.60 & 1.30 \\
\hline $\mathrm{FF}, \%$ & 80.38 & 77.09 & 74.07 & 70.30 & 65.08 & 58.67 & 51.21 \\
\hline$\eta, \%$ & 7.59 & 6.44 & 5.35 & 4.27 & 3.21 & 2.26 & 1.39 \\
\hline
\end{tabular}

Within the framework of the approach [17, 19, 20], the following equations are proposed to determine the temperature coefficients of the basic electrical parameters of solar cells.

Based on the temperature dependences of the $U O C$ and $J_{S C}$ values, their thermal coefficients can be calculated, respectively, as follows:

$$
\beta_{U_{c o}}=\frac{U_{o c}(T)-U_{o c}(300)}{U_{o c}(300)(T-300)},
$$

and

$$
\beta_{J_{s c}}=\frac{J_{s c}(T)-J_{s c}(300)}{J_{s c}(300)(T-300)}
$$


The thermal coefficients of the fill-factor and efficiency can also be determined by the appropriate ratios

$$
\begin{aligned}
& \beta_{\mathrm{FF}}=\frac{\mathrm{FF}(T)-\mathrm{FF}(300)}{\operatorname{FF}(300)(T-300)}, \\
& \beta_{\eta}=\frac{\eta(T)-\eta(300)}{\eta(300)(T-300)} .
\end{aligned}
$$

In this case, in the temperature range from 300 to $400 \mathrm{~K}$, the temperature coefficients $\beta_{U_{c o}}, \beta_{J_{s c}}, \beta_{\mathrm{FF}}$ and $\beta_{\eta}$ have values of $-6.67 \times 10^{-3},-0.53 \times 10^{-3},-3.36 \times 10^{-3}$ and $-7.84 \times 10^{-3} \mathrm{~K}^{-1}$. The obtained data on the values of the temperature coefficients are in good agreement with the experimental data for Si-based solar cells [15, 16]. Note that the temperature dependences for the values of $U_{O C}, \mathrm{FF}$ and $\eta$ are typical for solar cells of various types. However, in this case, there is a slight decrease in the value of $J_{S C}$ with increasing temperature, which is associated with an increase in the effect of surface recombination for nanowires. The maximum values of the cathode current, anode voltage and power in the operating temperature range from 280 to $340 \mathrm{~K}$ decrease by $7.50,66.67$ and $79.17 \%$, respectively. Such data also correlate well with the data $[17,18]$.

The typical light current-voltage characteristics simulated for coaxial $p-i-n$ structures of InP-based nanowire solar cells according to ambient temperatures of 280, 300, 340, 360, 380 and $400 \mathrm{~K}$ are shown in Fig. 4. The main electrical parameters of such photovoltaic converters are given in Table 2 . They are in good agreement with the experimental data [1,9] obtained under standard conditions.

In accordance with equations (1)-(4), the temperature coefficients $\beta_{U_{c o}}, \beta_{J_{s c}}, \beta_{\mathrm{FF}}$ and $\beta_{\eta}$ are determined in the temperature range from 300 to $400 \mathrm{~K}$ and have the corresponding values of $-2.21 \times 10^{-3},-0.37 \times 10^{-3}$, $-0.76 \times 10^{-3}$ and $-3.09 \times 10-3 \mathrm{~K}^{-1}$. The obtained data on the values of the temperature coefficients agree well with the experimental results for InP-based solar cells [17]. Along with this, the maximum values of the cathode current, anode voltage and power in the operating temperature range from 300 to $340 \mathrm{~K}$ decrease by 2.92 , 17.14 and $20.93 \%$, respectively. Such data also correlate well with the data [17].

The designed coaxial InP-based nanowire solar cells at room temperature have higher values of the opencircuit voltage, short-circuit current density, fill-factor and efficiency by $104.76,44.51,12.73$, and $235.56 \%$, respectively, compared to similar Si-based solar cells. The difference in the electrical parameters tends to increase with increasing temperature in the range from $400 \mathrm{~K}$. The data obtained indicate a higher thermal stability of InP-based photovoltaic converters. This conclusion suggests that direct band gap semiconductors have higher thermal stability than indirect band gap semiconductors, since the photon absorption in the latter is determined by the lattice vibrations, which depend on temperature.

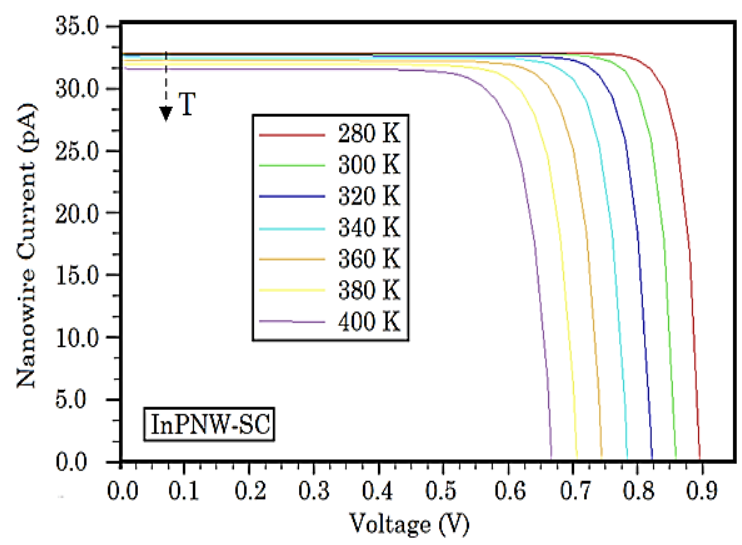

Fig. 4 - Light current-voltage characteristics of the InP-based nanowire solar cell as a function of temperature variations. The arrow direction indicates an increase in temperature

Table 2 - The parameters values used for the InP-based nanowire solar cell as a function of temperature variations

\begin{tabular}{|c|c|c|c|c|c|c|c|}
\hline $\begin{array}{c}\text { Para- } \\
\text { meters }\end{array}$ & $\mathbf{2 8 0} \mathbf{K}$ & $\mathbf{3 0 0} \mathbf{K}$ & $\mathbf{3 2 0} \mathbf{K}$ & $\mathbf{3 4 0} \mathbf{K}$ & $\mathbf{3 6 0} \mathbf{K}$ & $\mathbf{3 8 0} \mathbf{~ K}$ & $\mathbf{4 0 0} \mathbf{~ K}$ \\
\hline$U_{O C}, \mathrm{~V}$ & 0.90 & 0.86 & 0.82 & 0.78 & 0.74 & 0.71 & 0.67 \\
\hline $\begin{array}{c}J_{S C}, \\
\mathrm{~mA} / \mathrm{cm}^{2}\end{array}$ & 29.02 & 28.93 & 28.84 & 28.67 & 28.49 & 28.22 & 27.87 \\
\hline$U_{m}, \mathrm{~V}$ & 0.82 & 0.78 & 0.74 & 0.70 & 0.66 & 0.62 & 0.56 \\
\hline$I_{m}, \mathrm{pA}$ & 31.70 & 31.40 & 31.10 & 30.80 & 30.30 & 29.80 & 30.35 \\
\hline$P_{m, \mathrm{pW}}$ & 26.00 & 24.50 & 23.00 & 21.50 & 20.00 & 18.50 & 17.00 \\
\hline $\mathrm{FF}, \%$ & 88.11 & 86.90 & 85.75 & 84.55 & 83.24 & 81.82 & 80.32 \\
\hline$\eta, \%$ & 22.88 & 21.61 & 20.31 & 18.99 & 17.65 & 16.30 & 14.94 \\
\hline
\end{tabular}

\section{CONCLUSIONS}

The effect of temperatures in the range from 280 to $400 \mathrm{~K}$ on the current-voltage characteristics and electrical parameters of coaxial $p-i-n$ structures of nanowire solar cells based on $\mathrm{Si}$ and $\mathrm{InP}$ has been studied. The expressions for estimating the temperature coefficients $\beta_{U_{c o}}, \beta_{J_{s c}}, \beta_{\mathrm{FF}}$ and $\beta_{\eta}$ have been proposed, and their obtained values have shown good agreement with the experimental data. The typical temperature dependences can be explained according to the corresponding theory [15].

A typical higher thermal stability of the parameters of photovoltaic converters based on a direct band gap semiconductor (InP) compared to an indirect band gap semiconductor $(\mathrm{Si})$ has been noted.

The designed 3D structures within the framework of the drift-diffusion transport model with Fermi-Dirac statistics demonstrate the admissible values of electrical parameters: the open-circuit voltages $U_{O C}$, shortcircuit current densities $J_{S C}$, maximum power $P_{m}$, fillfactors FF, and photovoltaic efficiency $\eta$. For this reason, the results obtained can be used for further study of nanowire solar cells. 


\section{REFERENCES}

1. I. Protsenko, L. Odnodvoretz, A. Chornous, Metallofiz. Noveishie Tekhnol. 20, 1, 36 (1998).

2. O.V. Synashenko, O.P. Tkach, I.P. Buryk, L.V. Odnodvorets, S.I. .Protsenko, N.I. Shumakova, Probl. At. Sci. Technol. 6, 169 (2009).

3. Y.O. Shkurdoda, I.M. Pazukha, A.M. Chornous, Int. J. Miner. Metall. Mater. 24, 1459 (2017).

4. Y. Bereznyak, L. Odnodvorets, D. Poduremne, I. Protsenko, Yu. Shabelnyk, Springer Proceedings in Physics, 210, 17 (2018).

5. K.V. Tyshchenko, L.V. Odnodvorets, I.Yu. Protsenko, Metallofiz. Noveishie Tekhnol. 33(10), 1351 (2011).

6. V.N. Kuznetsov, A.A. Yanovska, A.G. Ryabyshev, Y.V. Khyzhnya, S.N. Danilchenko, J. Nano- Electron. Phys. 7(3), 03034 (2015).

7. I.M. Lukavenko, V.V. Andryushchenko, O.V. Yazykov, Springer Proceedings in Physics 244, 121 (2020).

8. I.M. Lukavenko, J. Nano-Electron. Phys. 12, No 5, 05005 (2020).

9. I.M. Lukavenko, J. Nano- Electron. Phys. 12 No 1, 01014 (2020).
10. Y. Zhang, H. Liu, Crystals 9, 87 (2019).

11. M.K. Sahoo, P. Kale, J. Materiomics 5, 34 (2019).

12. V. Raj, H.H. Tan, C. Jagadich, Asian J. Phys. 28 No 7-9, 719 (2019)

13. K.J. Singh, C. Leiphrakpam, N.P. Singh, IJCSA 4 No 3, 91 (2014).

14. S. Abdellatif, K. Kirah, Energy Procedia 36, 488 (2013).

15. Silvaco, ATLAS User's Manual Device Simulation Software (Santa Clara CA: Silvaco International: 2018).

16. R.V. Zaitsev, M.V. Kirichenko, G.S. Khrypunov, J. NanoElectron. Phys. 11 No 4, 04029 (2019).

17. O. Dupré, R. Vaillonet, M.A. Green, Sol. Energy Mater. Sol. Cells 140, 92 (2015).

18. O.V. Pylypova, A.A. Evtukh, P.V. Parfenyuk, Appl. Phys. A 124, 773 (2018).

19. I.P. Buryk, T.M. Hrychanovs'ka, D.V. Poduremne, A.O. Stepanenko, J. Nano-Electron. Phys. 10 No 5, 05026 (2018).

20. T.M. Grychanovs'ka, V.V Bibyk, I.P. Buryk, O.S. Gryschuk, L.A. Sheshenya, J. Nano- Electron. Phys. 5 No 1, 01014 (2013).

\title{
Моделювання параметрів коаксіальних сонячних елементів на основі нанодротів Si та InP
}

\author{
І.П. Бурик ${ }^{1}$, Л.В. Однодворець², Я.В. Хижня ${ }^{2}$
}

${ }^{1}$ Конотопський інститут Сумського державного університету, пр. Миру, 24, 41615 Конотоп, Украӥна ${ }^{2}$ Сулський державний університет, вул. Рилського-Корсакова, 2, 40007 Сули, Украӥна

Перспективним напрямом подальшого розвитку фотовольтаїки вважається застосування фротоелектричних перетворювачів сонячної енергії з нанодротовими елементами. Поряд 3 цим значний інтерес до властивостей нанодротів $\mathrm{Si}$, InP, GaAs та InGaN як елементів високоефективних фотоперетворювачів сформував новий напрям нанодротової фотовольтаїки. Найбільш актуальними $е$ дослідження структурних, оптичних, електричних, температурних та інших характеристик напівпровідникових нанодротів. У роботі представлено результати числового моделювання коаксіальних $p$ - $i$ - $n$ структур сонячних елементів на основі нанодротів $\mathrm{Si}$ та InP. Геометрія 3D структур, світлові та темнові вольт-амперні харакетристики були спроектовані з використанням інструментів Silvaco TCAD. B рамках дрейфр-дифузійної моделі транспорту із статистикою Фермі-Дірака отримано допустимі значення електричних параметрів: напруги холостого ходу $U_{O C}$, густини струму короткого замикання $J_{S C}$, максимальної потужності $P_{m}$, фрактора заповнення $\mathrm{FF}$, фороелектричної ефективності $\eta$ та інших. Досліджено температурну залежність вольт-амперних характеристик та електричних параметрів. В інтервалі температур від 300 до $400 \mathrm{~K}$ визначено температурні коефіцієнти напруги холостого ходу, густини струму короткого замикання, фрактора заповнення та ефективності для коаксіальних нандротових сонячних елементів на основі Si та InP. Зроблено висновок про високу термічну стійкість електричних параметрів для фотоелектричного перетворювача на основі InP, що характерно для прямозонних напівпровідників. Отримані результати чисельного моделювання мають добре узгодження з експериментальними даними та можуть бути застосовані для прогнозування властивостей нанодротових сонячних елементів.

Ключові слова: Нанодротовий сонячний елемент, Моделювання, Температурна залежність електричних параметрів. 